\title{
Mathematical approaches to the optimization of the functional and planning location of primary collection points of waste management collection according to city planning criteria
}

\author{
Liudmyla Zolotar \\ Kyiv National University of Construction and Architecture \\ 31, Povitroflotskyi Avenue, Kyiv, Ukraine, 03037 \\ luydmula.z@gmail.com, orcid.org/0000-0002-9031-2061
}

The manuscript was received on 20.09.2017 and was accepted after revision for publication on 09.10.2017

DOI: $10.26884 / 1707.1804$

\begin{abstract}
The main city planning criteria of residential area sanitation organization aimed at optimizing the location of primary collection points of waste management in residential areas are examined.

The trends in the development of residential areas waste collection systems and disposal to provide comfortable living environment for the population and to satisfy their household requirements are confined to the following trends: progressiveness of household waste collection automation, aesthetic, sanitary-and-hygienic, engineering solutions of equipping the primary waste collection points to ensure the technological and organization-and-technological methods for waste collection.
\end{abstract}

Further planning of the waste collection and disposal is impossible without taking into account the city planning and development. A decision on the technological or organization-and-technological method for the household waste collection is taken on the third or second technological level is based on the city planning and development standards, the territory analysis and is taken in accordance with a number of conditions and limitations specifying the territory.

The main city planning limitations when selecting a waste collection method are: the territorial limitation, the residential density within the limits of the streets, or the zone of influence of a waste transfer station, planning limitations of the existing site planning etc. The main requirement to the residential areas waste management and collection system envisaged by the city planning is

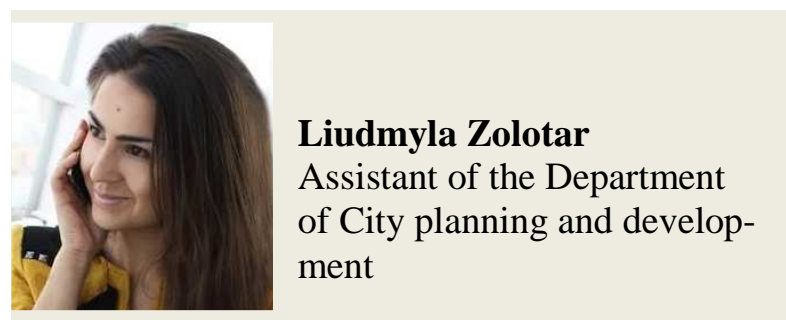

optimization of the location of the primary waste collection points on the residential territories.

The locations of planned hubs of the primary waste collection point are determined by the planning scheme of the territory waste collection system.

Keywords: household waste, primary collection point, waste collection systems, planning module, planned hubs, criteria, residential areas.

\section{INTRODUCTION}

The planning scheme of the waste collection points is developed for a territory at the stage of a detailed master plan of the territory at a scale of 1:2000, and is limited by the zone of influence of a waste transfer station, the city block area, or by the district of residential area in accordance with the distribution of the social and cultural services provided to the inhabitants. The main city planning criteria defining the territorial location of primary waste collection points are: 
- walking distance

- differentiation of the functional zone at the stage of the primary waste collection point planning

- lay of the land and landscaping

- economic models of planned hubs location

- residential density.

\section{STATEMENT OF BASIC MATERIAL}

The principle of the functional-and-planning organization is created according to the scheme shown in Fig.1.

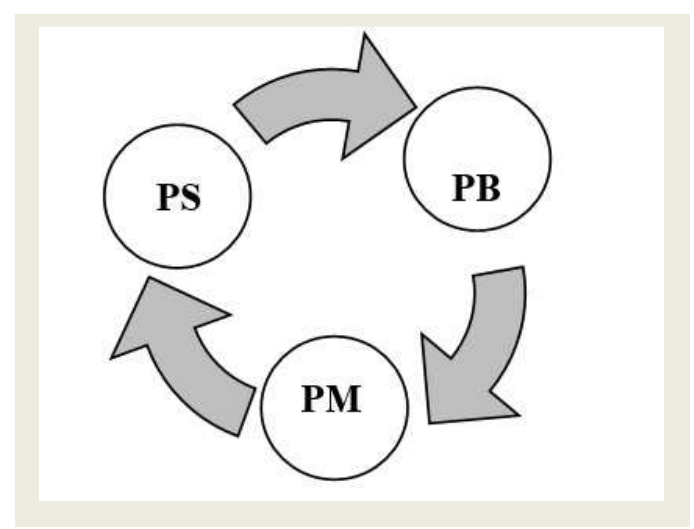

Fig.1. Scheme of organization of the residential area waste collection system planning structure

PS - planning scheme (at a 1:2000 scale) of the waste collection system is based on the city planning requirements and residential area limitations. In the area planning scheme the places of planned hubs of the primary waste collection point are defined. The area of the planning blocks influence is limited by the radius of walking distance and defines the territorial limits for calculation of the number of planning units (modules) of the primary waste collection point, see Fig.2.

PB - planning blocking or embedding the planning modules in the primary household waste collection point in a cartilage. The planning block area is calculated in accordance with the household waste volume in the influence zone and the working area of the primary waste collection point, see Fig.4 Blocking the planning modules.

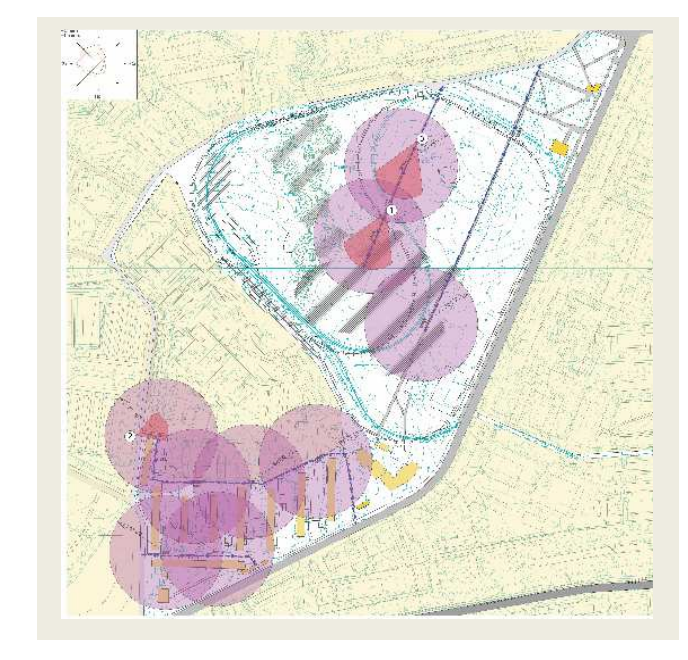

Fig.2. A fragment of a planning scheme of location of the primary waste collection points with the definition of their influence zone on the example of a residential area in Kyiv

PM - planning module (loading equipment) is the primary element in the waste collection and disposal system. The calculation of the planning module area depends on the equipment for the household waste collection system adopted according to [1] and pursuant to the determined waste collection method for the residential area, its constructive features and is defined in accordance with the principle planning scheme, see Fig.3.

A planning block is the smallest planning and organization unit of the waste collection system. In accordance with the Order of the Ministry of Regional Development, Construction and Housing, and Communal Services [2], a planning block corresponds to the first, second, third and fourth process flows. It is approved by the Order and is designed for one or two containers which, when a planned hub is formed, are blocked in accordance with the requirements of the area and the established technology.

The planning of the arrangement of a container [3] includes the distance between the equipment and fencing and the area under the fencing. The state standards do not provide the area of a module necessary for an individual to dispose of the household waste; this area is de- 
fined by the anthropometric measurements and is located on the side of the equipment opening [4, p.141-151], for PM2 the territory between the equipment is also included.

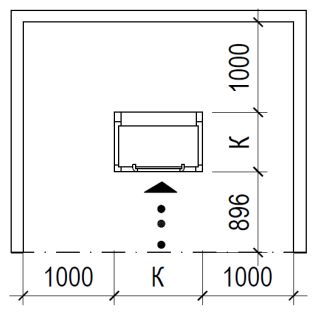

$a$

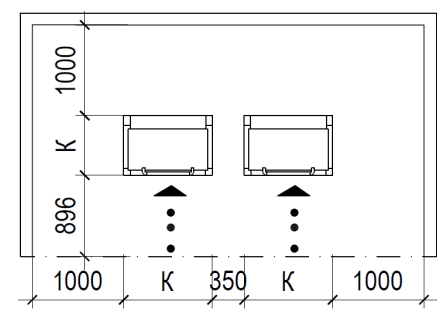

b

\section{LEGEND}

- equipment for the household waste collection points

... - direction of the household waste loading

$\sqcap$ - borders of a module area

Fig.3. Planning modules of the primary household waste collection point:

$a$ - planning module of the primary household waste collection point per one piece of equipment (PM1); $b$ - planning module of the primary household waste collection point per two pieces of equipment (PM2)

The length of the PM1 module for the landbased method is calculated according to the formula (1) [3]:

$$
L=2 b+K \text {. }
$$

The length of the PM2 module for the land - based method is calculated according to the formula (2),

$$
L=2 b+2 K+0,35 \text {. }
$$

The width of the modules PM1 and PM2 for the land - based method is calculated according to the formula (3) [3], with the addition of anthropometric measurements:

$$
B=b+K+0,875 \text {, }
$$

where: $K$ - the overall dimension of the container (length or width), $\mathrm{m} ; b$ - the distance from the container to the module fencing in line with the State Standard of Ukraine N.B.B.2.2-7:2013 (1 $\mathrm{m}$ is accepted); $B$ - the width of the module, $\mathrm{m}$.

When defining the length and width of a module for the underground method, the dimensions of the underground container are taken into account at calculation. Collection and transporting of the household waste by the land-based and underground method are the technically interconnected processes, whereas the reloading of the household waste from the equipment to the waste collection vehicle is carried out mostly mechanically and, only occasionally, manually. Both the land-based and the underground method of container emptying provide for the top, rear or side reloading to the waste collection vehicle [5, p.235-245].

It is important that the equipment fixing and size correspond to the technical capability of the waste collection vehicle [5, p.235-245]. The containers and the waste collection vehicle have special outlets for equipment, which clutch the equipment by special auxiliary handles thereon and with the help of the waste collectors holding it up (if necessary) from the opposite side when the container is being emptied.

The experience of technological method $[6,7]$ of the household waste collection system in residential areas in Ukraine is not represented, the household waste is mostly disposed by the land-based (Fig.5) and sometimes underground $[8,9]$ organizational and technological waste collection method. The equipment for the waste collection points is adopted in accordance with [1].

The morphological composition of the household waste puts a number of requirements as to the equipment form and to its material:

- food waste may attract stray animals, rats etc., therefore they have to be collected in the equipment with a lid, molded, and not of grid structure

- paper, plastic waste, PET bottles, rubber, fabric etc. are collected into the equipment of the molded, not grid structure with a lid, to avoid the waste scattering by wind in the territory 
- glass waste is collected into the equipment with the molded or grid structure

- batteries, accumulators and suchlike are collected into a specially allotted container of molded structure with a lid.

Depending on the volume of the household waste in the territory, the number of planning modules for the primary waste collection point is determined. For the household waste collection in Ukraine the containers with the volume of $1,1 \mathrm{~m}^{3}$ and $0,4 \mathrm{~m}^{3}$ are used, therefore a planning module has been developed for this type of equipment. Table 1 determines the area of a planning module for the equipment already in use in $90 \%$ of the cases of the household waste collection in residential areas in Ukraine.

Table 1. Area of a planning module for $0,4 \mathrm{~m}^{3}$ and $1,1 \mathrm{~m}^{3}$ volume equipment

\begin{tabular}{|c|c|c|c|c|}
\hline \multirow{2}{*}{$\begin{array}{c}\text { Waste col- } \\
\text { lection } \\
\text { method }\end{array}$} & \multicolumn{3}{|c|}{ Planning module area, $\mathrm{m}^{2}$} \\
\cline { 2 - 5 } & \multicolumn{2}{|c|}{$1 \mathrm{PM}$} & \multicolumn{2}{|c|}{$2 \mathrm{PM}$} \\
\cline { 2 - 5 } & $0,4 \mathrm{~m}^{3}$ & $1,1 \mathrm{~m}^{3}$ & $0,8 \mathrm{~m}^{3}$ & $2,2 \mathrm{~m}^{3}$ \\
\hline Land-based & 7,47 & 9,86 & 10,80 & 15,97 \\
\hline $\begin{array}{c}\text { Underground, } \\
\text { vacuum }\end{array}$ & \multicolumn{2}{|c|}{3,43} & \multicolumn{2}{|c|}{5,40} \\
\hline
\end{tabular}

A planned hub is the second level of the organizational - and - planning structure of the waste collection system. Blocking the primary modules into a planned hub is carried out using two types: the front and off-center. The front blocking of planning modules envisages placing containers in one line, where the loading is carried out on one side or on two sides. The off - center location of containers envisages blocking with offset of the one planning module respective to the other, and loading is carried out from two or more sides.

The number of planning modules shall correspond to the limitations indicated in Chapter III of the Order of the Ministry of Regional Development, Construction and Housing, and Communal Services On Separate Household Waste Management [2]. It is achieved by taking into account the process flow of the household waste collection system in residential areas where the maximum planned hub number of equipment on the enclosure may vary from two to five.

The blocking of planning modules into a hub is based on the principle of decreasing their area while interoperating on the average per $2 . .5 \mathrm{~m}^{2}$ (see Fig.4). Principle scheme of blocking the planning modules into hubs of two types: front and off-center.

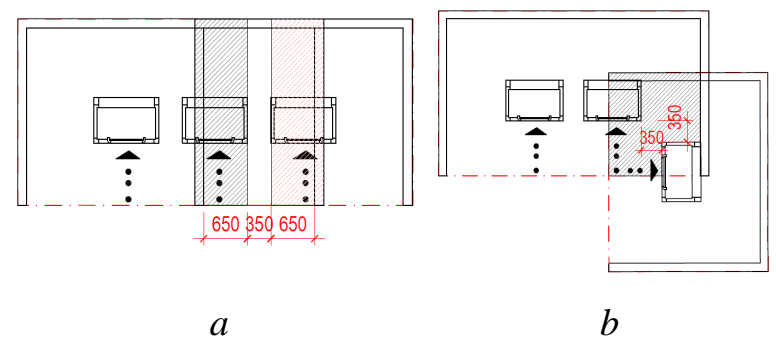

LEGEND

- equipment for the household waste collection points.

... - direction of the household waste loading

$\sqcap$ - borders of the module area

Fig.4. Principle scheme of PM blocking into hubs of two types: with front and off center location: $a$ - principle scheme of PM blocking into planned hubs with front location; $b$ - principle scheme of PM blocking into planned hubs with offcenter location

The decision on combining the planning modules into a planned hub is taken locally in accordance with city planning conditions and the planning scheme of the waste collection system, which is prescribed in technical requirements:

- the square footage for the primary waste collection point;

- the location of the primary waste collection point in the planning organization of the city block area.

The number of planning modules in a planned hub is 3 to 5 in accordance to the process flow of the Order of the Ministry of Regional Development, Construction and Housing, and Utilities Services [2], as well as aesthetic, sanitary-and-hygienic norms. Negative experience of blocking hub (see Fig.5). 

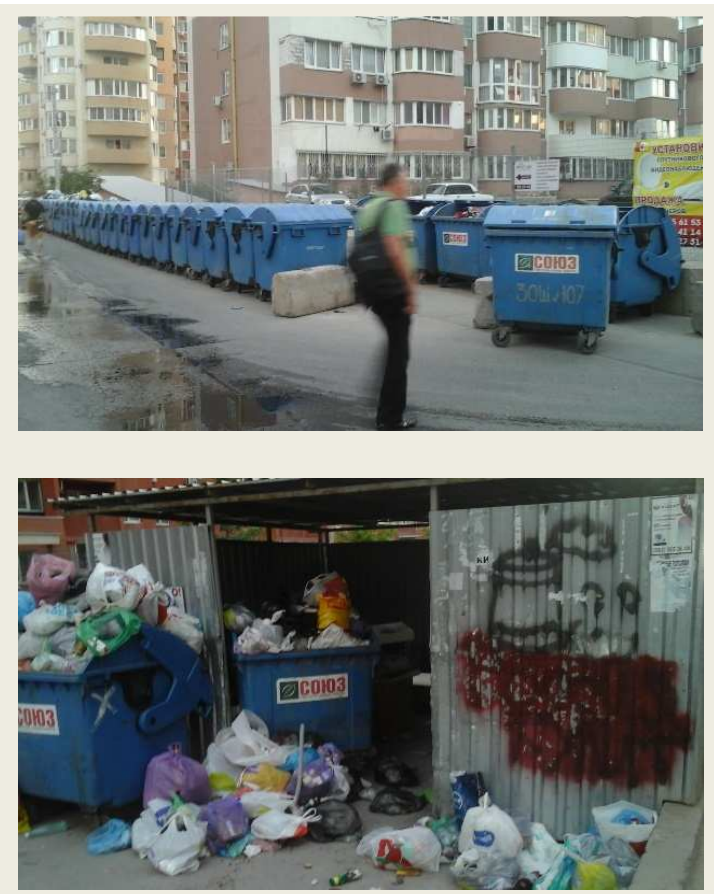

Fig.5. Blocking of planning modules of the primary waste collection points, on the example of Odessa city
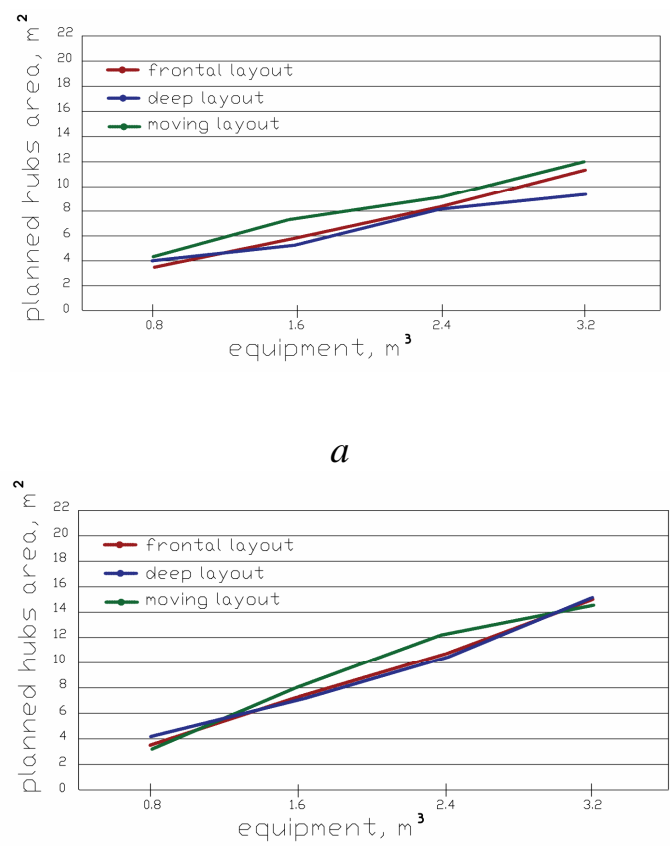

$c$
After the method for the household waste collection and the planned hub type (its blocking) have been established, the functional zone of the primary waste collection point is determined which meets the function of the household waste accumulation. The functional planning dependence of the type of planned hub blocking is expressed through comparison of the functional zone area of the primary waste collection point with its accumulation volume in different disposal methods (see Fig.6). The criterion for optimizing the primary waste collection points blocking is shown below, where

$$
S f \rightarrow \min ,
$$

$S f \quad-$ is the functional zone area.

The planned hub functional zone provision can be expressed through the theory of sets, Fig.7:

$A \in C ; B \in C$

$A / B ; \quad B / A$,

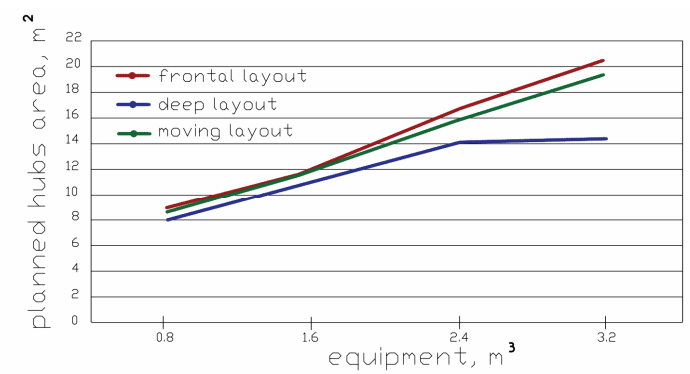

$b$

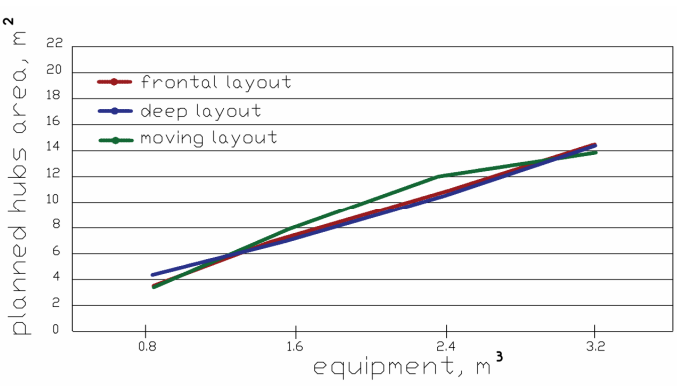

$d$

Fig.6. Functional planning dependence of the type of the primary waste collection point planned hub blocking: $a$-land-based method; $b$-land-based method with vegetal zone; $c$ - underground method; $d$-vacuum method 


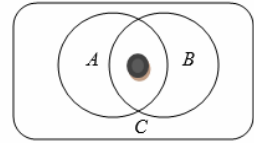

$a$

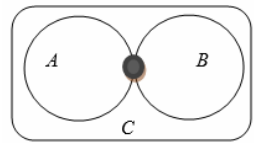

$b$ LEGEND

- planned hub

$A$ - loading zone (pedestrian area)

$B$ - disposal zone (working area)

$C$ - planned hub functional zone

Fig.7. Functional planning of the primary waste collection point planned hub blocking: $a$ - planned hub with zone overlapping; $b$ - planned hub differentiation

where: $A$ - the household waste planned hub loading zone (pedestrian area); $B$ - the planned hub household waste disposal zone (waste collection vehicle working area); $C$ - the planned hub functional zone.

The walking distance $(l)$ determines the influence zone of the primary waste collection point and the area of planned hub influence. A maximum walking distance from a building entrance to the primary waste collection points is defined by the city planning norms and does not exceed 100 meters:

$$
l \leq 100
$$

To determine the primary waste collection point influence zone, the walking distance of 100 meters is accepted and expressed with due consideration of the nonlinearity coefficient as a radius of the primary waste collection point influence zone [10, p.107-112]. Location of the primary waste collection point planning hubs determining the borders of a maximum influence zone has to be optimal.

The criterion for optimization of the planned hub of the waste collection points is comfortable residential area for all inhabitants. Its provision indicators are expressed by the equal walking distance from the building entrances to the places of the waste collection disposal points with the equal utility payment rates for the waste collection services for all inhabitants of the residential area.

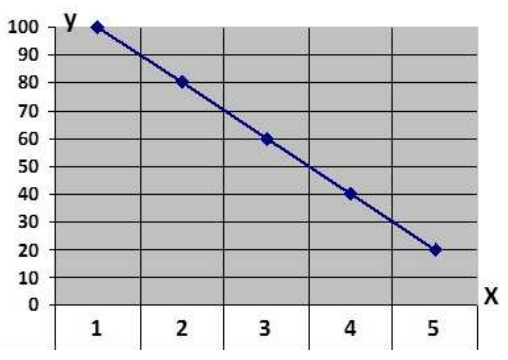

Fig.8. Distance to planned hubs in accordance with comfortable walking distance scheme: $x$ - resident comfort index on a scale from 1 to 5 , where 5 being the highest comfort index; $y$ - distance from the apartment block entrance to a planned hub

Determination of planned hubs of waste collection points for a residential area on a planning scheme is expressed by the equidistance parameter after the service apartment blocks have been defined.

$$
l_{1}=l_{2}=l_{3}=l_{n} \text {. }
$$

With the increase of the distance from a building entrance to the primary waste collection point the comfort index and accessibility of the planned hub for the residents' decreases, see Fig.8. The plotting of the planned hubs location is based on the parameter of decreasing the distance for a person to be covered to the primary waste collection point in order to improve the living convenience through the walking distance:

$$
l \rightarrow \min .
$$

In practical application these two functions have a series of contradictions, as it is practically impossible to provide a minimum equal distance from all entrances covered by the primary waste collection point influence zone with due consideration of the city planning conditions.

Therefore, the optimization of the location of planning hubs with the aim of increasing the living convenience through walking distance is based on the parameter of decreasing of the 
distance from the building entrances to the planning hub within its influence zone. In order to provide the minimum distance to the primary waste collection point it will be expedient to minimize the net distance from all the buildings to the planning hub:

$$
\sum l=l_{1}+l_{2}+l_{3}+l_{n} \rightarrow \min
$$

City block area (quarter) perimeter and buildings: depending on the territory configuration, lateral length in the plan and the planning type, the primary waste collection points may be located in the recess of the quarter on the main driveways and along the perimeter of the quarter without entering the residential area. In the city historical environment and when the streets are crossed more often than in $400 \mathrm{~m}$ the approach to the quarter area is forbidden. The primary waste collection points have to be located along the perimeter of the quarter area. Architectural objects of the residential, cultural and social purpose, which under this condition are located at a distance exceeding $100 \mathrm{~m}$, are serviced by the vacuum waste collection method. Location of the primary waste collection points allows to distinguish two major functional and planning types:

- the differentiation of the loading zone and the disposal zone with delimitation of the pedestrian and transport flow to the planning hub

- the combination of the loading zone and the disposal zone with crossing the pedestrian and transport flow.

The criterion by which the planned hub location is optimized is the equal living convenience for all the residents, the provision of which for population is expressed through the planning division of a hub into a waste load zone and a waste disposal zone.

Urban road network system of resident ar$e a$ in accordance with [11] imposes a series of requirements to the household waste planning hub location within the red lines [12]. In accordance with Annex B, p.44-47 [11], the most commonly used typical cross sections of streets and roads, the following requirements may be distinguished:
- location on the type I and IV trunk lines, see the scheme at p.44, Annex B [11], may only take place in zones allotted for the landscaping, and servicing and removal may be fulfilled through the local (side) service roads;

- location on the type II and III trunk lines is possible on the rumble and safety margin strips, as well as on the barrier railings strip providing their sufficient width.

The same requirements are imposed to location of the planned hubs on other cross sections of the trunk roads and housing streets, the main passages and local streets. When disposing the household waste by the underground method (container or vacuum), taking into account the layout of utilities is obligatory. The criterion by which the planned hub location on the streets and roads is optimized is the provision of unimpeded pedestrian and traffic flow. The planning charting of the planned hubs location is based on the parameter of optimization of location of separation of the traffic and pedestrian flow to the planned hub.

Area lay of the land and landscaping: one of the criteria of the comfortable living of the population is the city territory landscaping and public amenities. In [13], certain requirements to the enclosures for the household waste collection are given, with the recommendation of their landscaping, and in the State Sanitary Rules and Regulations [14] and in [1] and [3], the recommendations on the equipment selection are provided.

Having analyzed the standard efforts to regulate the residential area landscaping and public amenities, one can affirm that the waste management system requires more significant attention as it belongs to one of the population's primary needs. The waste management system is an integral part of landscaping of its residential environment and does not take into account the existing lay of the land, the territory landscaping, the waste collection system technology.

At the stage of the planning charting, when locations of planned hubs and waste collection method are determined, it is important to take into account the natural and climatic factors, 
wind direction, temperature range and lay of the land.

The lay of the land influences the waste collection and disposal system if a curtilage is located on a challenging lay of the land or on one that is unfavorable or adverse for residential planning [15, Table 1.1]. In a curtilage on a lay of the land where the battering walls, bent surfaces, hills and barrows, junctions of three plains [15, Fig.1.3] with the drop exceeding 2 meters are present, the primary waste collection points are built into the land with due organization of the working and functional zones. The walking distance to the primary waste collection point where the challenging lay of the land or a particularly adverse hill or steps occur has to be decreased. When locating the primary household waste collection points, it is necessary to take into account the solutions of the curtilage lay of the land organization to provide rinsing of containers and the wastewater disposal for the public utility site.

The landscaping in the territory has to be compulsory and not recommended for the land-based enclosures as its additional isolation from the household.

The wind direction and the curtilage aeration influences the location of the primary waste collection points and is a compulsory factor to be considered for the land-based method.

The temperature range influences the processes running in food waste; therefore, for a temperate climate zone it is necessary to consider this factor to calculate the periodicity of the household waste disposal. However, this factor does not influence the planning location of the primary waste collection points.

Economic models of planned hub location: one of the principles of economically and rational location of the primary waste collection points is its compactness principle. The compactness principle is expressed through the economic models of locating the primary waste collection point and the volume of household waste in its influence zone, see Fig. $9, a$ and $b$, the maximum influence zone of the primary waste collection point equals the area of the circle with a $100 \mathrm{~m}$ radius:

$$
S_{\text {inf } l . z}=\pi r^{2},
$$

where $S_{\text {inf } l . z}-$ is the maximum influence zone according to the walking distance radius $=3,14$ hectares. Fig. 9 show the developed economical models of the primary household waste collection points location for a residential area within the maximum radius of accessibility of the primary waste collection point which constitutes an influence zone of 3,14 hectares. The residential density of the area determines the economic effectiveness of each of the location models:

- in the centrally separated model and in the centrally integrated economic model under the condition of such population concentration it is difficult to find a territory in a city to block 4 containers with a volume which would satisfy all the requirements to the organization of a functional and working zone of the primary waste collection point

- the centrally separated and the centrally integrated economic models under the condition of such residential density may function only on condition that the household waste would be removed twice a day, which increases the cost of the system operation and decreases the residents' comfort

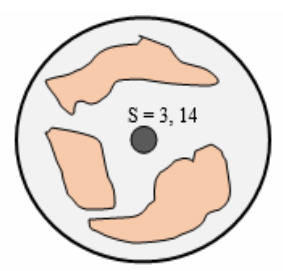

$a$
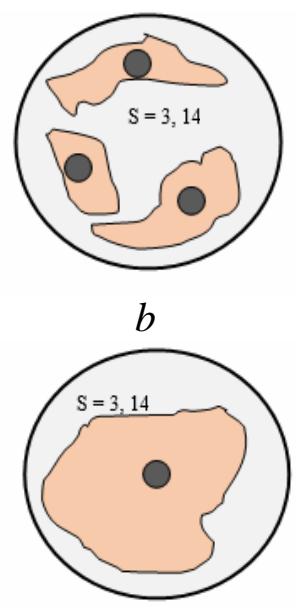

LEGEND

- places of the household waste formation

- influence zone

- primary waste collection point

Fig.9. Economic models of planning block location in influence zone: $a$-centrally separated; $b$ - fragmentary; $c$ - centrally united 
- the fragmentary model, on condition of the population's density in the territory requires additional primary waste collection points that increases the cost of the system construction and operation.

At the maximum residential density in the influence zone of $1200-1400$ persons at the rate of $400-450$ persons per hectare the household waste volume will reach $6 \ldots 9 \mathrm{~m}^{3}$ per day. The land-based method: such residential density in the influence zone gives evidence of the fact that location of one household primary waste collection point is not enough, as the maximum load on one primary waste collection point through the land-based method is $5,5 \mathrm{~m}^{3}$ per day (4 containers with the volume of $1,1 \mathrm{~m}^{3}$ ). Thus, in order to satisfy the household waste disposal by the landbased method the additional expenses in any economic model type are required.

The underground method: such residential density in the influence zone gives evidence of the fact that such centrally separated and centrally integrated economic models may be used without any additional expenses if this does not contradict technical provisions. The fragmentary model if population is dense on the territory requires additional primary waste collection points that increases the expenses for the system construction and operation and increases inhabitants' comfort by decreasing the walking distance. When the residential density is moderate, in the influence zone of $470-600$ persons at the rate of $150 \ldots 200$ per hectare the household waste volume will amount to $2 \ldots 4$ $\mathrm{m}^{3}$ per day.

The land-based method: such residential density in the influence zone gives evidence of the fact that locating one primary household waste collection point is enough, as the maximum load on one primary waste collection point by the land-based method is up to $5,5 \mathrm{~m}^{3}$ per day (4 containers with the volume of 1,1 $\mathrm{m}^{3}$ ). The fragmentary model, under the condition of the moderate residential density in the territory requires additional primary waste collection points, which increases expenses for the system construction and operation.
The underground method: such residential density in the influence area gives evidence of the fact that such centrally separated and centrally integrated economical models may be used without any additional expenses if this does not contradict technical provisions. The fragmentary model, if the population is dense in the territory, requires additional primary waste collection points that increases the expenses for the system construction and operation and increases the inhabitants' comfort by decreasing the walking distance.

Based on the analysis of the models of the primary waste collection points location and the residential density it is necessary to stress that the land-based method is not of economic benefit for a territory with high residential density (mostly central and historical city parts), therefore there the underground method can be used efficiently.

Generally, for a territory with high residential density it is better to use the fragmentary model, as these are the zones of compact planning and it is quite difficult on the conditions of such planning to find a significant territory area to equip an enclosure for 4 containers, to isolate it from the inhabitants and to provide a working and functional service zone for it; besides, such enclosures look unaesthetic in the central and historical city parts. For a territory with low residential density, the centrally separated or the centrally integrated models are more appropriate, as they are rational from the economic point of view.

$$
\text { Vp.f. } \rightarrow \max
$$

The economic criteria by which the location of the planning hub is optimized the provision of maximum accumulation of the household waste.

\section{CONCLUSION}

The functional and planning location of the primary waste collection points is provided by a number of criteria. To optimize their location two major city planning factors are taken into account: the minimization of the walking distance from the buildings' entrances and the lo- 
cation of the primary waste collection points in the concentration places (places of high residential density) in the influence zone. This is meeting the economic efficiency criterion (maximum volume accumulation in the primary waste collection points) and comfortability for the largest part of the population in the influence zone.

This way of optimization may be provided if the primary waste collection point can be viewed as an attraction center. The second optimization criterion is the use of the planning conditions and territory limitations,

$\begin{array}{ll}\text { where } & S f \rightarrow \min \\ \text { when } & V p . f . \rightarrow \max .\end{array}$

\section{REFERENCES}

1. DSTU 8476:2015. Containers for solid household waste. General Technical Requirements. Order No. 118 dated 28.09.2015 of the Ukrainian Research and Development and Training Centre for Standardization, Certification and Quality, State Enterprise.

2. Order of the Ministry of Regional Development, Construction and Housing and Utilities Services of Ukraine No.133 dated 01.08.2011. On Separate Household Waste Collection, registered at the Ministry of Justice of Ukraine under the No.1157/19895 on 10.10.2011.

3. DSTU N.B.B.2.2-7:2013. Guide on Container Enclosure Arrangement. Order No.506 dated 22.10.2013 of the Ukrainian State Research Institute of Problems of Water Supply, Water Removal and Environmental Protection "UkrVODHEO" of the Ministry of Housing and Utilities Infrastructure of Ukraine.

4. Zolotar L., 2014. The main schemes, structural representation and classification of elements of the waste collection system in residential areas. City and Land Use Planning: Scientific and Technical Compilation. Kyiv, KNUBA, Iss.52, 489.

5. Zolotar L., 2012. The functional and planning zone of primary collection points of household waste defined. City and Land Use Planning: Scientific and Technical Compilation. Kyiv, KNUBA, Iss.46, 694.

6. Envac concept, 2007. Magazine from the world leader in automated waste collection (C) Envac, Available at: www.envac.net.
7. Vacuum technology. Latest update August 2009. () Envac AB. Available at: www.envac.net.

8. FAQ, 2009. The Stationary vacuum system, Edition-1, Latest update September, (C) Envac, Available at: www.envac.net.

9. Fundició Dúctil Benito, S.L.: Underground Waste catalogue. Available at: http://www. benito.com/ru/downloads-mobiliario.

10. Golubenko V., 2013. City and Land Use Planning: Scientific and Technical Compilation. Kyiv, KNUBA, Iss.50, 827.

11. Ukraine's National Building Code B.2.35:2001. Streets and Roads of Populated Areas. Kyiv, State Committee on Development and Architecture of Ukraine, 50.

12. Priymachenko Olexij, 2017. Model for effectiveness evaluation of planning measures for protection of areas surrounding main roads from the influence of environmental pressures on the Kyiv main road network. Underwater Technologies, Vol.05, 67-73.

13. DBN. B.2.2-5:2011. Urban Land Improvement. Kyiv, Ministry of Regional Development Construction and Housing and Utilities Services of Ukraine, 61.

14. Ministry of Healthcare of Ukraine. Order No.145 of 17.03.2011. On Approval of State Sanitary Norms and Rules of populated areas' territories maintenance.

15. Kuznetsova I., 2011. Lay of land planning of Urban Territories: Textbook. Omsk, SibADI, 98.

16. Glazychev V.L., Yegorov, M.M., Ilyina, T.V. and others, 1995. City Environment. Planning technology: Desk book illustrations. Moscow, Publishing office Ladya, ISBN 5-7068-0084-7, 240.

17. Andrushchenko V.P., Astakhova, V.I., Bekh, V.P., 2002. Social work textbook. Kyiv Institute of Higher Education of the APS of Ukraine. State Centre of Youth Social Services, Book II, 440.

18. Integrated Waste Collection, 2011. Volume I, Edited by Er. Sunil Kumar, ISBN 978-953307-469-6, 538.

19. Krogius V.R., 1979. City and Lay of the Land, illustrated. Moscow, Strtoyizdat, 124.

20.Aleksandrovskay Z.I. and other, 1976. Organization of west system and city cleaning service. Moscow, Stroyizdat, 127.

21. Text edition on solid household waste landfill monitoring, 2004. Donetsk, Tacis, 291.

22. Gutnov A.E., 1984. Evolution of Urban Planning, illustrated. Moscow, Stroyizdat, 256. 
23. Ukraine's National Building Code $360-92 * *$ 2002. City Planning Development of Urban and Rural Settlements. Kyiv, State Committee of Development and Architecture of Ukraine, 113.

24. Waste collection: domestic and foreign practices, 2008. Textbook edited by O.I. Bondar. Kyiv, Aiva plus Ltb, 196.

\section{Математические подходы оптимизации функционально-планировочного размешения первичных пунктов сбора санитарной очистки по критериям городского планирования}

\section{Людмила Золотарь}

Аннотация: рассмотрены основные градостроительные критерии организации санитарной очистки жилых территорий для оптимизации размещения первичных пунктов сбора на жилых территориях.

Тенденции развития санитарной очистки жилых территорий для обеспечения комфортного проживания населения и его бытовых нужд ограничивается направлениям: прогрессивность автоматизации сбора бытовых отходов, эстетическое, санитарно-гигиеническое, инженерное решение оборудования первичных пунктов сбора бытовых отходов для обеспечения технологического или организационнотехнологического способа сбора.
Дальнейшее развитие санитарной очистки невозможно без принципиального учета градостроительства. Решение по технологическом или организационно технологическом способе сбора бытовых отходов принимается на третьем или втором технологическом уровне и базируется на градостроительных требованиях и анализа территории, принимается в соответствии с рядом условий и ограничений, характеризующих территорию.

Основные градостроительные ограничения при выборе способа сбора: территориальное ограничение, плотность населения территории в пределах улиц, или зоне влияния мусороперегрузочной станции, планировочные ограничения существующей застройки и др.

Основное требование к санитарной очистки жилых территорий, которую ставит градостроительство - оптимизация размещения первичных пунктов сбора на жилых территориях.

Ключевые слова: бытовые отходы, первичная точка сбора, способы сбора бытовых отходов, планировочный модуль, планировочный узел, критерии, жилые районы. 